\title{
Polarized functions and permeability properties of rat epididymal epithelial cells in vitro
}

\author{
S. W. Byers' ${ }^{1}$, S. Citi ${ }^{2}$, J. M. Anderson ${ }^{3}$ and B. Hoxter ${ }^{1}$ \\ ${ }^{1}$ Department of Anatomy and Cell Biology and the Lombardi Cancer Centre, Georgetown \\ University Medical and Dental Schools, 3900 Reservoir Road, NW, Washington DC 20007 (202) \\ 687-1813, USA; ${ }^{2}$ Department of Cell Biology and Anatomy, Cornell University Medical College, \\ 1300 York Ave, New York, NY, USA; and ${ }^{3}$ The Division of Digestive Diseases, School of Medicine, \\ Yale University, New Haven, Connecticut, USA
}

\begin{abstract}
Summary. Cultured rat caput and cauda epididymidal epithelial cells are shown to exhibit polarized properties characteristic of functioning epithelia. When grown on plastic substrates coated with reconstituted basement membrane, confluent monolayers of cells from both regions formed domes characteristic of other transporting epithelia. Immunocytochemical localization of three proteins characteristically associated with epithelial junctional complexes revealed that uvomorulin, zonula occludens 1 and cingulin were present in cultured epididymal epithelial cells and that their distribution was similar to that in the epididymal epithelium in vivo. These three molecules were not found in epididymal stromal cells. Cells from both regions growing in two compartment chambers developed an electrical resistance across the monolayer with a magnitude characteristic of high resistance epithelia. The optimal plating density of cells was $0.75 \times 10^{6}$ cells $\mathrm{cm}^{-2}$. The presence of reconstituted basement membrane on the filters did not affect the resistance of the cells. Inulin passage from basal to apical chambers was less than $2 \%$ over $24 \mathrm{~h}$. These results show that several polarized functions of epididymal epithelial cells can be maintained in culture and that this type of culture system is useful for studying the function of the epididymis in vitro.
\end{abstract}

Key'words: epididymis; cell culture; permeability; rat; uvomorulin; zonula occludens 1; cingulin

\section{Introduction}

Immature spermatozoa leaving the testis acquire the ability to become motile and to fertilize eggs during transit through the epididymis (Bedford, 1975; Cooper, 1986). Although the epididymal epithelium is probably essential for sperm maturation, its precise role is largely unknown. Proteins are secreted into the epididymal lumen by the epithelial cells (Lea et al., 1978; Brooks \& Higgins, 1980; Jones et al., 1980; Klinefelter \& Hamilton, 1985), which also take up other proteins from the lumen (Attramadal et al., 1981; Pelliniemi et al., 1981; Djakiew et al., 1984, 1985). Some molecules from the systemic circulation are excluded by the epithelium, whereas others are taken up and even concentrated (Hinton et al., 1979; Hinton \& Howards, 1981, 1982; Hoffer \& Hinton, 1984). To learn more about the functions of the epididymis, a number of research groups have isolated and cultured these cells (Kierszenbaum et al., 1981; Klinefelter et al., 1982; Olson et al., 1983; Byers et al., 1985).

A common criticism of experiments carried out with isolated and cultured cells is that the results obtained may not reflect the function of these cells in vivo. In epithelial cells in general, and epididymal epithelial cells in particular, maintenance of the distinct polarity of the cell is certainly required for fully differentiated function. In vivo, the epididymal epithelial cells are highly polarized 
(Hamilton, 1975). Tight junctions near the apical surface divide the membrane into two distinct regions. The apical plasma membrane communicates directly with the luminal environment and is presumably intimately involved in both secretion and uptake of specific proteins and other molecules directly involved in sperm maturation. The basolateral membrane is exposed to the systemic circulation (albeit modified by peritubular cells and extracellular matrix) and is probably involved largely in the uptake of nutrients. A third and particularly important function of the epithelium is to protect the maturing spermatozoa from the immune system.

To become polarized in vitro, epithelial cells must assemble and maintain junctional complexes. Molecules associated with the zonula occludens and zonula adherens junctions characteristic of epithelial cells in vivo must therefore be expressed in vitro. Uvomorulin, a member of the cadherin class of cell adhesion molecules (Gumbiner et al., 1988) is responsible, at least in part, for the initiation and maintenance of adhesive interactions among epithelial cells. It is also thought that uvomorulin-mediated cell adhesion is a prerequisite for the assembly of tight junctional complexes (Gumbiner et al., 1988). Zonula occludens 1 and cingulin are peripheral membrane proteins associated with the cytoplasmic surfaces of occluding junctions in epithelial cells (Stevenson et al., 1986; Citi et al., 1988; Byers et al., 1991). These three molecules must not only be expressed in vitro but also be organized appropriately for junctional complex assembly and the resulting polarization of the epithelial cells. In other fluid-transporting epithelial cells that have successfully assembled junctional complexes, functional polarity in vitro is expressed as an accumulation of fluid beneath the monolayer and the formation of hemicysts or domes (Lever, 1985).

Conventional cell culture systems do not permit investigations of the polarized functions of epithelial cells. We have shown that polarized monolayers of epididymal epithelial cells and Sertoli cells can be maintained in dual environment culture chambers (Byers et al., 1986). This report shows that, as well as having a polarized morphology, epididymal epithelial cells in vitro express and appropriately organize uvomorulin, zonula occludens 1 and cingulin, and form hemicysts. We also show that cells growing in dual compartment chambers establish a permeability barrier and an electrical resistance characteristic of high resistance epithelia.

\section{Materials and Methods}

\section{Cell isolation and culture}

Epididymal epithelial cells were isolated from either the caput-corpus or cauda epididymidis of 40-50-day old rats. The epididymides were divided at the isthmus of the corpus epididymidis. After a single collagenase (GIBCO) digestion for $6090 \mathrm{~min}$ (Byers et al., 1985), free tubule fragments were incubated with $0.2 \%$ pronase (Sigma, P5147) in Hank's balanced salt solution free of calcium and magnesium to release sheets of epithelial cells (Olson et al., 1983). This isolation procedure differs from that described earlier (Byers et al., 1985) as it was necessary to reduce the size of the fragments of epithelium plated to get a more even monolayer than could be obtained using two collagenase digestions. Epididymal stromal cells were isolated as described previously (Byers et al., 1985). Cells were plated at a density of $0 \cdot 5-2 \cdot 0 \times 10^{6}$ cells $\mathrm{cm}^{-2}$ on Millicell HA culture chambers (Millipore Corporation, Bedford, MA, USA) impregnated with Matrigel (Collaborative Research, Lexington, MA, USA). The Matrigel was first diluted 1:7 in sterile distilled water and air dried in the Millicells to coat the filters. This resulted in a thinner $(1 \mu \mathrm{m})$ more even layer of basement membrane than could be obtained using the undiluted material. The initial volume of medium in the upper chamber was $2 \mathrm{ml}$ and that in the lower chamber $1.5 \mathrm{ml}$ when large chambers $(30 \mathrm{~mm}$ ) were used (inulin permeability experiments). For electrical resistance measurements, cells were grown in $12 \mathrm{~mm}$ chambers with initial apical and basal volumes of $0.6 \mathrm{ml}$. Monolayers were used for inulin permeability and electrical resistance studies after 4-6 days. Cells were grown in serum-free defined medium (Byers et al., 1985). Some cells were also plated on Matrigel-coated plastic petri dishes, uncoated plastic dishes and uncoated Millicells.

\section{Immunocytochemistry}

Antibodies to uvomorulin, zonula occludens 1 and cingulin were used for immunocytochemistry on methanolfixed $4 \mu \mathrm{m}$ frozen sections of epididymis and on cells growing on Matrigel-coated glass coverslips (Byers et al., 1988). Affinity-purified rabbit polyclonal antibody to zonula occludens 1 fusion protein (Anderson et al., 1989) was used at a 
dilution of 1:100. Rabbit polyclonal antiserum to the extracellular domain of uvomorulin (Schuh et al., 1986) was used at a dilution of 1:200 and rabbit polyclonal antiserum to whole cingulin was used at a dilution of 1:500 (Citi et al., 1988).

\section{Inulin permeability and electrical resistance measurements}

After 6 days in culture, four $30 \mathrm{~mm}$ Matrigel-coated chambers from each region were incubated in $\left[{ }^{3} \mathrm{H}\right] \mathrm{methoxyinulin}$ $\left(1 \mu \mathrm{Ci} \mathrm{ml}^{-1}\right.$ in the basal chamber). After $1,3,6$ and $24 \mathrm{~h}$, aliquots of medium from both compartments were collected and the radioactivity was measured. Results were expressed as a percentage of the original radioactivity added to the basal chamber present in the apical medium. This experiment was also carried out with Matrigel-coated chambers in the absence of cells. Electrical resistance across monolayers of cells was measured using a transepithelial resistance device (Millipore Corporation, Bedford, MA, USA). Care was taken to ensure that fluid volumes in the apical chambers were at the same level for each chamber measured. Small differences in the fluid levels made small ( $20 \%)$ but measurable differences in the resistance measurements, owing to variations in the length of the electrode immersed. This was most important at the early time points before a complete monolayer was established.

\section{Results}

\section{General comments on the cell cultures}

Epithelial cells were isolated from the epididymides of six pubertal animals which were usually 40-50 days old. At this time spermatozoa were beginning to enter the tubules, but were not present in large numbers. When older animals were used, it was more difficult to achieve consistent confluent monolayer formation, as the cultures were more likely to be contaminated with nonepithelial cell types. Yields of cells were remarkably consistent among cultures, with a range of 5.0 $8.2 \times 10^{6}$ cells per rat for the caput-corpus, and $3.0-5.4 \times 10^{6}$ cells per rat for the corpus-cauda epididymidis. Cell yields were much lower when long-term castrated rats were used $\left(1.66 \times 10^{6}\right.$ cells per rat for both caput and cauda). Cell counts were carried out originally by digesting an aliquot of the final cell preparation to single cells and counting with a haemocytometer. In later experiments the number of cells was estimated by measuring the volume of the final cell pellet after centrifugation in a $15 \mathrm{ml}$ calibrated centrifuge tube $(80 \mathrm{~g}$ for $5 \mathrm{~min}), 50 \mu \mathrm{l}$ of cell pellet being equivalent to $15 \times 10^{6}$ cells.

\section{Dome formation}

Confluent monolayers of cells formed after 3-5 days in culture. At this time, if cells were growing on Matrigel-coated plastic, many areas of the cultures from both regions of the epididymis had formed hemicysts or domes (Fig. 1). This phenomenon has been described in a number of epithelial cell lines (Lever, 1985). The domes were formed by an accumulation of fluid beneath the epithelial cells, a result of vectorial transport. Dome formation was not observed when cells were growing on permeable supports or on impermeable supports in the absence of Matrigel. Incubation of cultures for $1 \mathrm{~h}$ at $4^{\circ} \mathrm{C}$ resulted in the collapse of most of the domes (data not shown).

After 10 days in culture, the epithelial cell monolayers became patchy (Fig. 2). This was not due to a simple detachment of cells from the substrate but to a folding of the epithelium. At this time, many tubule-like structures were observed floating freely in the medium. It was, therefore, important to carry out studies of the polarized function of these cells before this time.

\section{Immunocytochemical localization of uvomorulin, zonula occludens 1 and cingulin}

In sections of epididymis, uvomorulin was distributed in a pattern consistent with a concentration at sites of apical junctional complexes (Fig. 3a). This was observed as a bright honeycomb of staining at the apical part of the epithelium, which presumably corresponds to the zonula adherens or belt desmosome, which lies basal to the tight junction. Uvomorulin was also localized over the rest of the basolateral plasma membrane but the staining intensity was reduced. No 

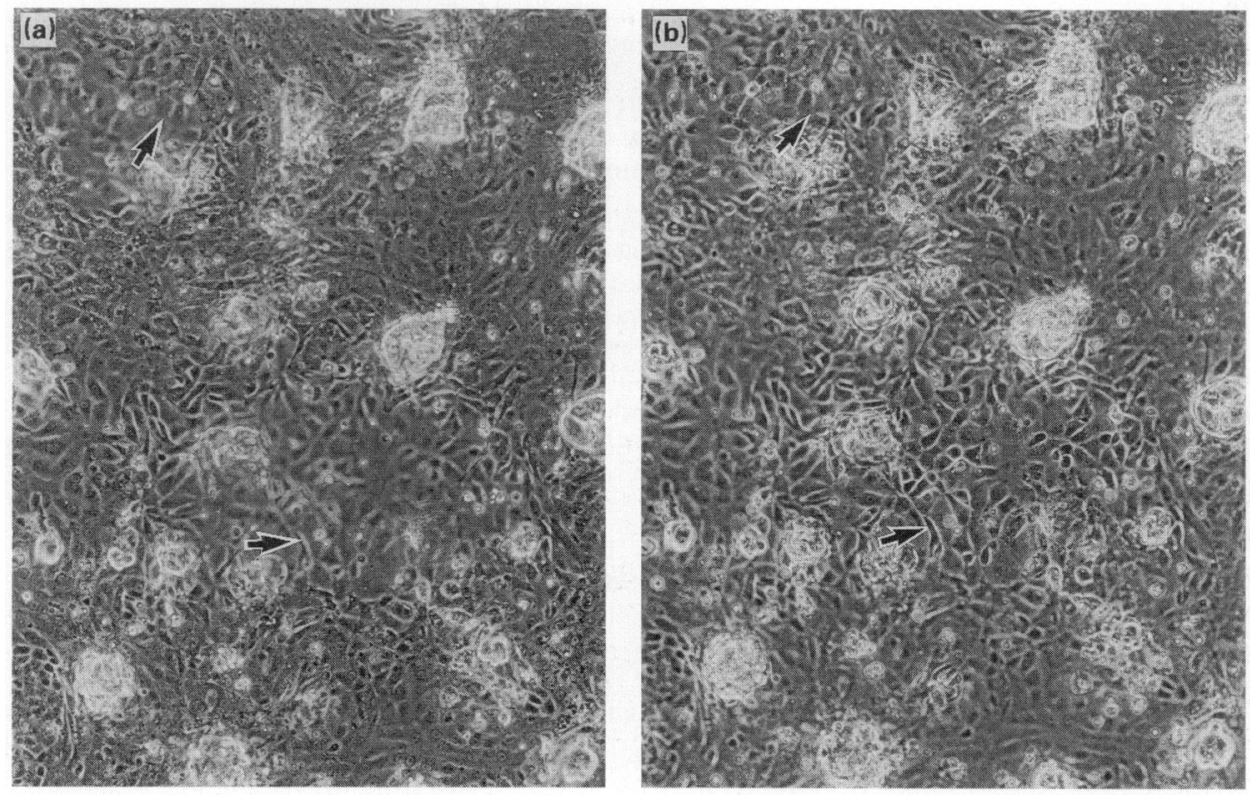

Fig. 1. Paired phase contrast micrographs of rat epididymal epithelial cell monolayers growing on Matrigel-coated plastic after 4 days in culture. Dome formation (arrows) is shown in monolayers isolated from the caput epididymidis $(\times 75)$. (a) The monolayer is in the plane of focus and (b) the domes are in focus.
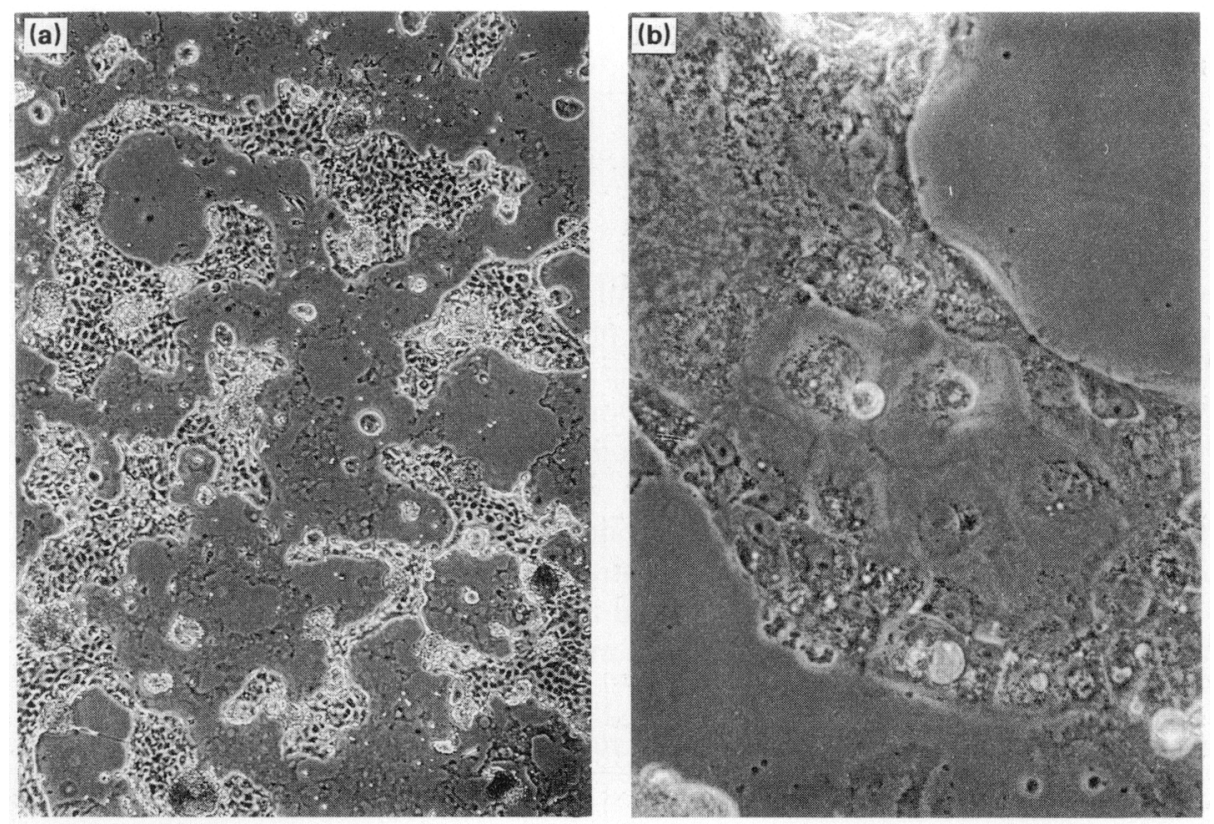

Fig. 2. (a) Micrograph of rat cells isolated from the cauda epididymis after 9 days in culture $(\times 75)$. The cell layer is patchy. Many tubule-like structures were observed floating in the medium above the cells. (b) Higher power micrograph $(\times 300)$ of rat cells after 9 days in culture. The edges of this region were folding in to form a cord or tubule. 
specific staining of the epididymal interstitium was observed. In cultured cells from both regions of the epididymis, uvomorulin staining was concentrated at the cell periphery at regions of cell-cell contact (Fig. 3b-d). In areas of the monolayers that had formed hemicysts, uvomorulin was present on cells that formed the hemicysts as well as on the surrounding epithelial cells (Fig. 3b,c). In cells at subconfluent densities, uvomorulin staining was more concentrated on parts of the epithelial cells in contact with other cells and was considerably less intense on the free borders (Fig. $3 \mathrm{c}$ ). In co-cultures of stromal cells and epididymal epithelial cells, stromal cells were completely negative (Fig. 3e).

In sections of the epididymis, both cingulin and zonula occludens 1 were distributed as discrete rings of staining at the apical part of the epithelial cells (Figs 4a, 5a). No staining of the rest of the basolateral membrane was observed. Tight junctions of endothelial cells were also stained but no other cells in the epididymal interstitium exhibited specific staining. The zonula occludens 1 antibody also stained spermatozoa in the lumen of the epididymis. This particular antibody preparation was purified immunoglobulin $\mathrm{G}(\mathrm{IgG})$, not serum. At similar concentrations, purified rabbit IgG also stained spermatozoa but did not give the characteristic zonula occludens 1 ring-like staining (not shown). Since it has been shown that spermatozoa do have receptors for the constant region of IgG (Sethi \& Brandis, 1980), we interpret this staining of spermatozoa as an interaction of the purified IgG with these Fc receptors. The other antibodies were whole sera preparations in which the IgG concentration at the effective dilution for immunostaining was considerably less than that required for staining for zonula occludens 1 .

Cultured epithelial cells showed a similar pattern of staining. Cingulin and zonula occludens 1 were localized as a fine ring of staining around the borders of epithelial cells that were in contact with one another (Figs 4b, 5b). As with uvomorulin, no staining of the free borders of epithelial cells or stromal cells was observed. Controls, including normal rabbit serum or purified IgG instead of primary antibody, and omission of one or more steps of the immunocytochemical procedure, did not show staining.

\section{Inulin permeability and electrical resistance}

Complete monolayers of cells from proximal and distal regions were remarkably impermeable to inulin passage from basal to apical compartments with a rate of $0 \cdot 1 \% \mathrm{~h}^{-1}$ for the proximal and $0.05 \% \mathrm{~h}^{-1}$ for the distal epididymidis, respectively (Fig. 6).

We were interested in the effect of cell density on the development of electrical resistance. We found that densities of $>1.0 \times 10^{6}$ per chamber $\left(1.6 \times 10^{6} \mathrm{~cm}^{-2}\right)$ actually delayed and in some instances prevented, the development of significant resistance (Fig. 7). The deleterious effects of high initial plating density were probably the result of many cells failing to attach under these conditions. Some chambers did eventually develop resistance, probably a result of the surviving cells dividing and forming a monolayer. The appropriate initial plating density for both regions was $0.75 \times 10^{6}$ cells $\mathrm{cm}^{-2}$. Even at these ideal densities, $30 \%$ of the chambers did not develop a high resistance ( $>200 \mathrm{ohms}$ ). The large standard deviations at certain times reflected the inclusion of values for chambers that did not establish high resistance. Many chambers eventually established resistances exceeding the limits of the detector $(>2000 \mathrm{ohms})$ and these values were included in the results as $2000 \mathrm{ohms}$. Despite these variations, it was clear that cells from both regions formed high-resistance, impermeable monolayers in vitro. Epithelial cells in those chambers that did not develop a resistance may have been contaminated with nonepithelial cells. Our demonstration that uvomorulin, zonula occludens 1 and cingulin were specifically expressed in epithelial cells indicates that these markers could also be used to establish the purity of cell culture preparations. Indeed, we found that an initial contamination of $>10 \%$ of nonepithelial cells was sufficient to prevent the development of high-resistance monolayers (authors' unpublished observations).

For experiments of polarized protein secretion, inulin permeability and transport studies, chambers with an electrical resistance of more than $500 \mathrm{ohms}$ were selected. At an initial cell 

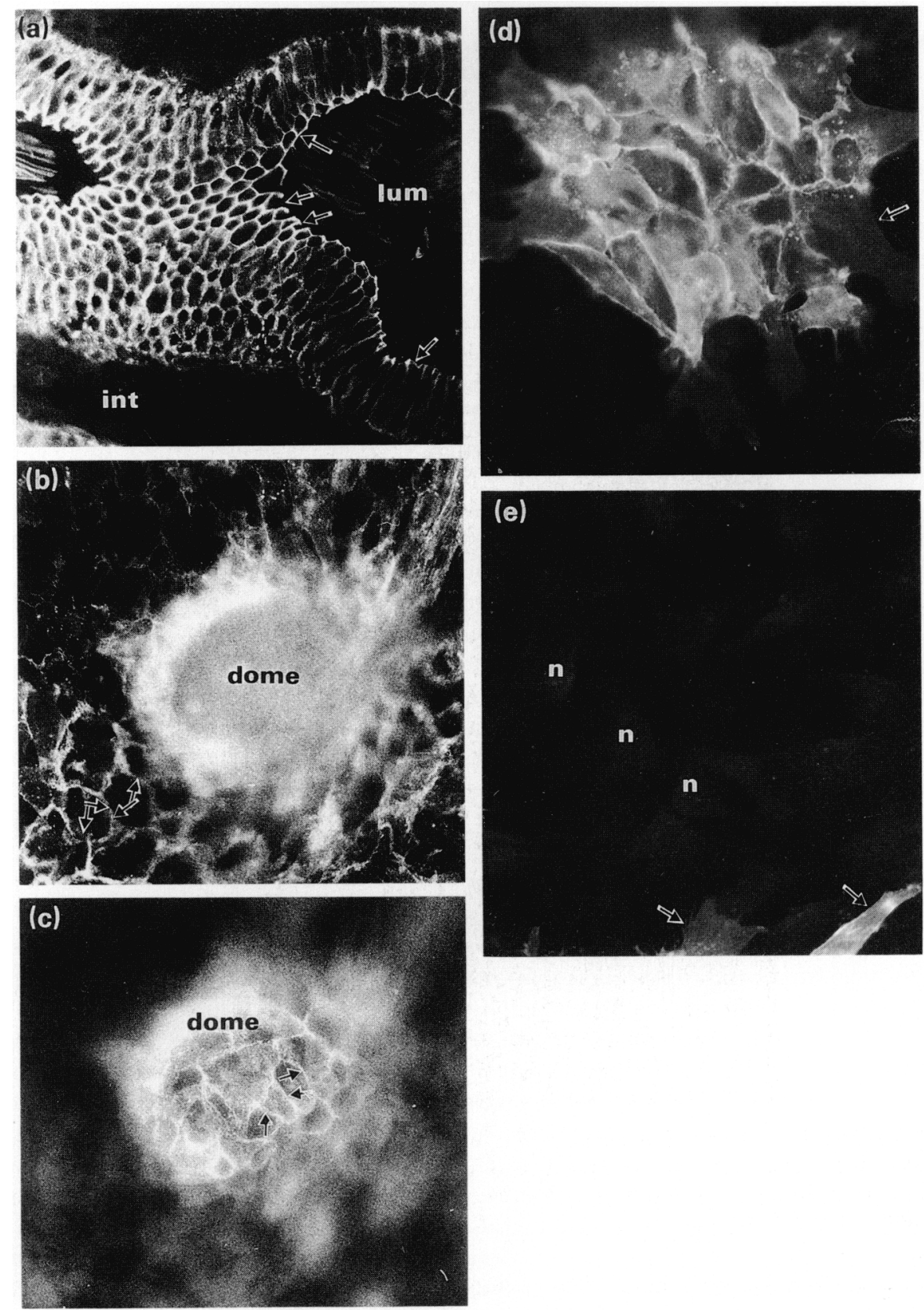

Fig. 3. (a) Uvomorulin immunostaining of the rat epididymis. Specific staining was concentrated as a ring at the apical surface of the cells (arrows), but was also present on the rest of the basolateral plasma membrane. lum: lumen; int: interstitium. (b) Uvomorulin immunostaining of rat epididymal cells in culture. A dome was seen in the centre of the field. The cells within the dome were out of focus and the staining of the cells surrounding this was concentrated at the cell horders (arrows). (c) Uvomorulin staining of the cells in the dome. The borders of the cells were specifically stained (arrows). (d) A colony of rat epididymal epithelial cells stained for uvomorulin. Note that the staining was concentrated at the cell borders where adjacent cells were in contact (small arrows) but was less intense at the free borders (large arrowheads). (c) Stromal cells in co-culture with epithelial cells were negative for uvomorulin. n: nucleus; large arrowheads indicate epithelial cells at the edge of the field. $(\times 280$.) 

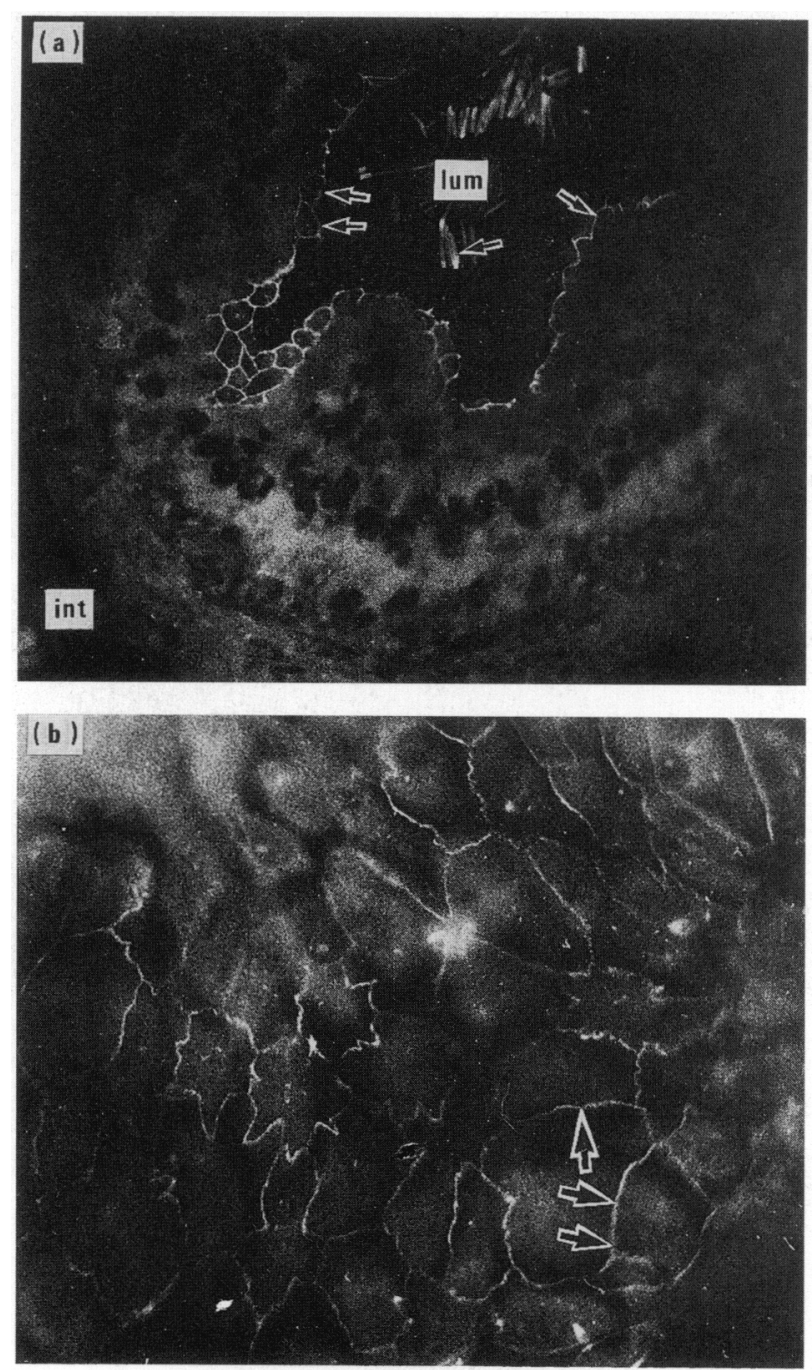

Fig. 4. (a) Cingulin staining of rat epididymis. Note that staining was restricted to a honeycomb (arrows, tight junctions) at the apical part of the cells. lum: lumen: int: interstitium. (b) Cingulin staining of epididymal epithelial cells in culture. Arrows indicate the staining restricted to the cell borders.

density of $1.0 \times 10^{6}$ cells per chamber, there was no difference in the resistances of cells growing on uncoated or Matrigel-coated filters (Fig. 8). It was clear from these experiments that not all chambers could be used to investigate vectorial functions. The routine measurement of electrical resistance was essential before selecting chambers for use in such studies.

\section{Discussion}

We have shown that epididymal epithelial cells and Sertoli cells can be maintained as morphologically polarized monolayers on permeable supports coated with extracellular matrix (Byers et al., 1986) and demonstrated the transferrin-mediated transcytosis of iron and the polarized secretion of androgen-binding protein and transferrin by Sertoli cells in culture (Djakiew et al., 1986; Hadley 

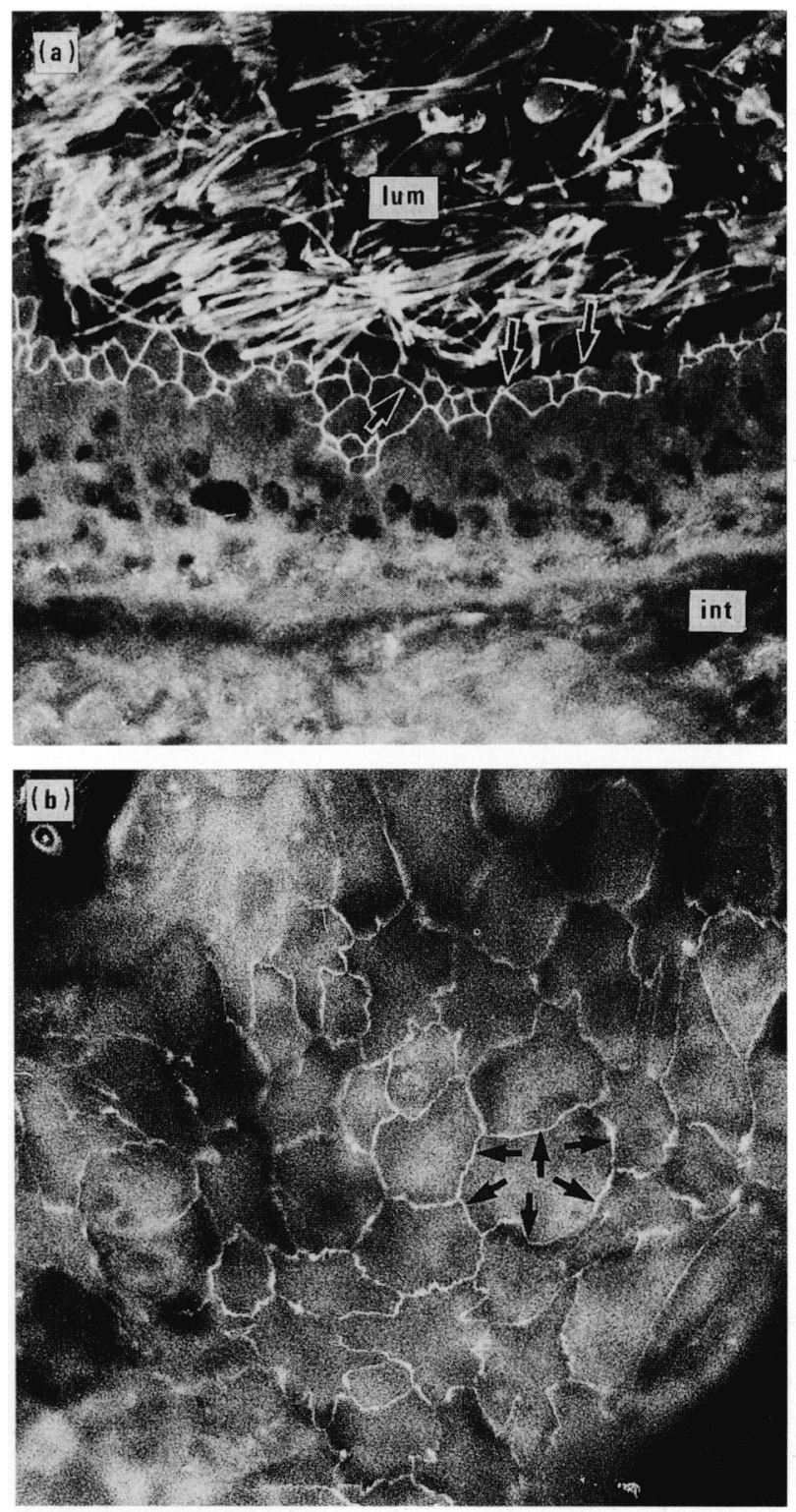

Fig. 5. (a) Zonula occludens 1 staining of the epididymis. Staining was restricted to a honeycomb (arrows, tight junctions) at the apical part of the cells. lum: lumen; int: interstitium. (b) Zonula occludens 1 staining of epididymal epithelial cells in culture. Arrows indicate the staining restricted to the cell borders.

et al., 1987). The present experiments show that cultured epididymal epithelial cells express adhesive and junctional proteins and form a permeability barrier when grown in a two-chamber culture system.

Dome formation in epithelial cell cultures is acceptable presumptive evidence that a number of polarized functions are being expressed (see Lever, 1985 for review). Lifting of the epithelial cell layer, owing to active transport of ions and water across the cell monolayer in an apical to basolateral direction, traps a bubble of fluid between the cell layer and the culture dish resulting in 


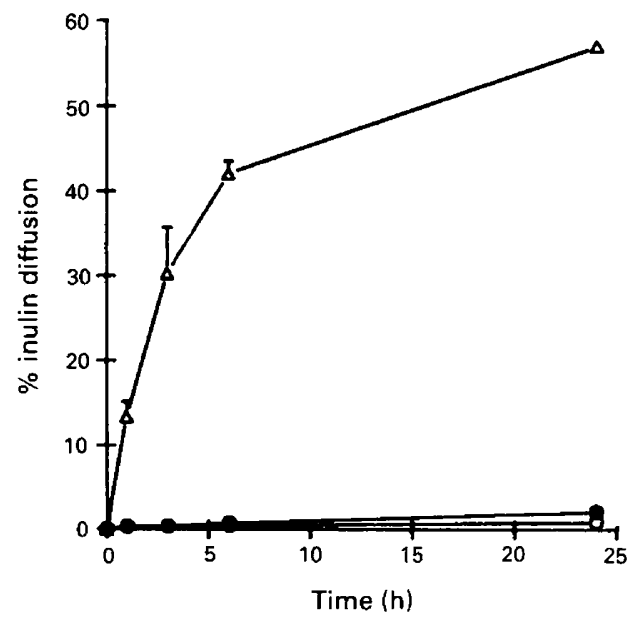

Fig. 6. $\left[{ }^{3} \mathrm{H}\right]$ inulin permeability of monolayers from the proximal $(O)$ and distal $(O)$ regions of the epididymis. $(\triangle)$ Permeability of the matrix coated filter alone. \% diffusion is the percentage of the original radioactivity added to the basal chamber present in the apical chamber at the times indicated. Data are means \pm SEM.
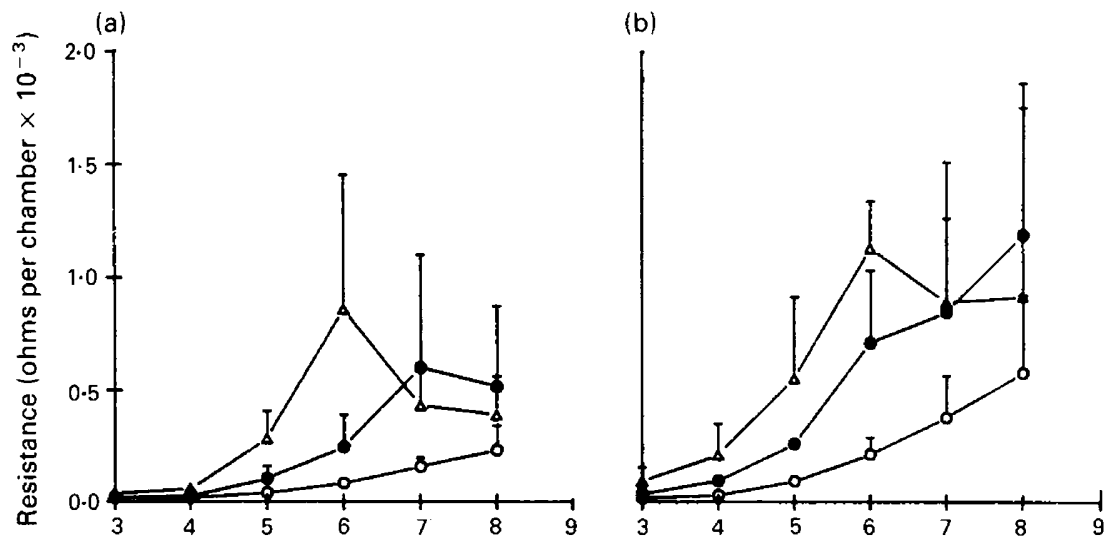

Days in culture

Fig. 7. Electrical resistance of cell monolayers from the (a) proximal and (b) distal regions of the rat epididymis growing on Matrigel-coated filters. Cells were plated at $2.0 \times 10^{6}$ cells per chamber $(\bigcirc), 1.0 \times 10^{6}$ cells per chamber $(\Theta)$ and $0.5 \times 10^{6}$ cells per chamber $(\triangle)$. Error bars indicate the SD of results from three chambers.

the formation of domes which can be viewed by microscope. For this to occur, three fundamental processes must take place: (i) cell-cell adhesion and the formation of adherens and occluding junctions, (ii) plasma membrane polarization resulting in the restriction of ion pumps to the appropriate membrane domain and (iii) vectorial transepithelial ion transport. In the present study, we demonstrated the uvomorulin, zonula occludens 1 and cingulin molecules associated with adherens and occluding junctions (Stevenson et al., 1986; Citi et al., 1988; Gumbiner et al., 1988), are present and appropriately organized in cultures of epididymal epithelial cells. In earlier studies, we observed the presence of adherens and occluding junctions at the electron microscope level (Byers et al., 1985, 1986). We recently localized $\mathrm{Na}^{+}-\mathrm{K}^{+}$ATPase to the basolateral plasma membrane of the epididymal epithelium in vivo (Byers \& Graham, 1990). Isolated epididymal 


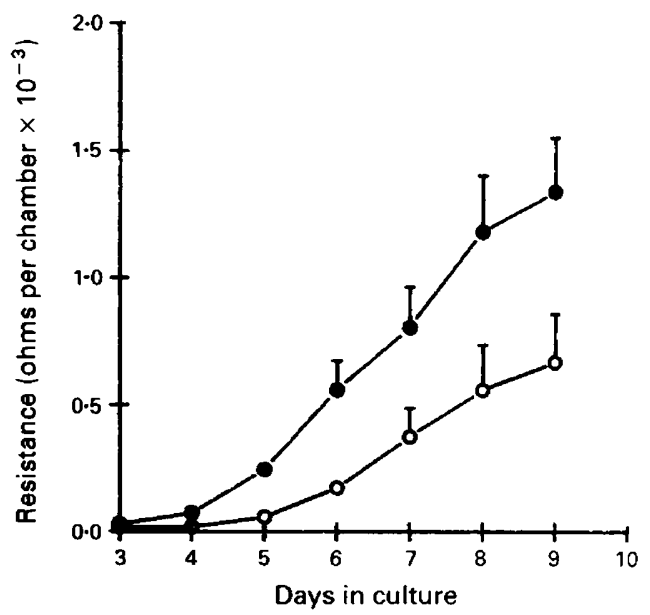

Fig. 8. Cells from the proximal $(O)$ and distal $(\bigcirc)$ regions of the rat epididymis were grown at $1.0 \times 10^{6}$ cells per chamber on uncoated filters. Electrical resistance was measured daily. Error bars indicate the SD of results from six chambers.

epithelial cells growing in Boyden chambers also carry out vectorial ion transport (Wong, 1988). These observations and the ability of epididymal epithelial cells to form domes in culture provide evidence that these cells are functionally polarized in vitro. The presence of domes was more obvious in cultures growing on Matrigel, possibly indicating that extracellular-matrix-cell interactions are needed for polarized functions in this system. Alternatively, the Matrigel-plastic interface may be more easily displaced by accumulating fluid than the cell-plastic interface. Matrigel is not required for epididymal epithelial cells growing in culture chambers to establish high resistance monolayers. We have not noticed dome formation in confluent and apparently polarized monolayers of Sertoli cells, perhaps because these cells are involved in fluid secretion from their apical, rather than basolateral, surface.

The relative impermeability to inulin of the epididymal epithelium in vitro in the present study differs from that reported previously (Byers et al., 1986; Cooper et al., 1989). There may be several explanations for this. First, the cells in the earlier studies may have undergone the folding and tubule formation described here, with a concomitant increase in inulin permeability. Second, at the time of our previous study, chamber construction was not always consistent; we now use commercially available Millicells. Third, we now use younger animals and achieve more reproducible results. The inulin permeability of epididymal cells in vitro in our study compares favourably with that described for high resistance epithelia (Simons \& Fuller, 1985); indeed, our electrical resistance measurements indicate that the epididymal epithelium in vitro falls into this category. Other cells in this category include the high resistance strain of the Madin Darby Canine Kidney (MDCK) cell line and the A6 toad bladder epithelial line (see Simons \& Fuller, 1985 for review). Confluent monolayers of Sertoli cells in culture do not approach this resistance or inulin impermeability in vitro, despite the presence of extensive tight junctional complexes (Hadley et al., 1985; Byers et al., 1986; Djakiew et al., 1986; Janecki \& Steinberger, 1986; Ailenberg \& Fritz, 1988; Onoda et al., 1990). The role of the various structural components of occluding junctions in epithelial resistance is not well defined. Neither the number of junctional strands nor the relative amounts of the tightjunction associated protein zonula occludens 1 correlate with electrical resistance in low and high resistance strains of MDCK cells (Stevenson et al., 1988). The molecular and structural basis underlying differences in electrical resistance among the various types of epithelia in the reproductive system, and elsewhere, is therefore not clear.

In this paper we have described several factors that are important in the isolation and culture of polarized monolayers of epididymal epithelial cells: (i) cells must be plated at the correct cell 
density, (ii) routine electrical resistance measurements must be made and (iii) great care must be taken to ensure that the isolated cells are at least $90 \%$ epithelial. We showed that several of the polarized functions of the epididymal epithelium can be preserved in vitro. This, with the effective separation of apical from basal compartments possible in dual-compartment chambers, should permit more meaningful in vitro studies of the role of the epididymis in sperm maturation.

We are grateful to R. Kemler of the Max Planck Institute for Immunobiology, Freiberg, Germany, for providing the uvomorulin antibody. Supported by NIH HD 20028, NIH HD 23744 (SWB) and by grants from the Rockefeller and Mellon Foundations.

\section{References}

Ailenberg, M. \& Fritz, I.B. (1988) Control of levels of plasminogen activator activity secreted by Sertoli cells maintained in a two-chamber assembly. Endocrinology 122, 2613-2621.

Anderson, J.M., Van Itallie, C.M., Peterson, M.D., Stevenson, B.R., Carew, E. \& Mooseker, M.S. (1989) ZO-I mRNA and protein expression during tight junction assembly in Caco-2 cells. Journal of Cell Biology 109, 1047-1056.

Attramadal, A., Bardin, C.W., Gunsalus, G.L., Musto, N.A. \& Hansson, V. (1981) Immunocytochemical localization of androgen binding protein in rat Sertoli and epididymal cells. Biology of Reproduction 25, 983-988.

Bedford, J.M. (1975) Maturation, transport and fate of spermatozoa in the epididymis. In Handbook of Physiology Vol. 5, pp. 303-317. Eds D. W. Hamilton \& R. O. Greep. American Physiological Society, Washington.

Brooks, D.E. \& Higgins, S.J. (1980) Characterization and androgen dependence of proteins associated with luminal fluid and spermatozoa in the rat epididymis. Journal of Reproduction and Fertility 59, 363-375.

Byers, S.W. \& Graham, R. (1990) Distribution of sodium-potassium ATPase in the rat testis and epididymis. American Journal of Anatomy 188, 31-43.

Byers, S.W., Djakiew, D. \& Dym, M. (1985) Structural characteristics of epididymal epithelial cells in vitro. Journal of Reproduction and Fertility 75, 40I-411.

Byers, S.W., Hadley, M.A., Djakiew, D. \& Dym, M. (1986) Growth and characterization of polarized monolayers of epididymal epithelial cells and Sertoii cells in dual environment culture chambers. Journal of Andrology 7, 59-68.

Byers, S.W., Richardson, L. \& Parker, C.C. (1988) Isolation and characterization of epididymal epithelia! cell plasma membranes. Biology of Reproduction 38, 201-209.

Byers, S.W., Graham, R., Dai, H.-N. \& Hoxter, B. (1991) Development of Sertoli cell junctional specializations and the distribution of the tight junction associated protein ZO- 1 in the mouse testis. American Journal of Anatomy 191, 35-47.

Citi, S., Sabanay, H., Jakes, R., Geiger, B. \& KendrichJones, J. (1988) Cingulin, a new peripheral component of tight junctions. Nature 333, 272-275.

Cooper, T.G. (1986) The Epididymis, Sperm Maturation and Fertilization. Springer-Verlag, Berlin.

Cooper, T.G., Yeung, C.H. \& Meyer, R. (1989) Immature rat epididymal epithelial cells grown in static primary monolayer culture on permeable supports. I. Vectorial secretion. Cell and Tissue Research 256, 567-575.

Djakiew, D., Byers, S.W. \& Dym, M. (1984) Receptormediated endocytosis of alpha2-macroglobulin and transferrin in rat caput epididymal epithelial cells in vitro. Biology of Reproduction 31, 1073-1085.

Djakiew, D., Byers, S.W., Lewis, D.M. \& Dym, M. (1985) Receptor mediated endocytosis of alpha2. macroglobulin by principal cells in the proximal caput epididymis in vivo. Journal of Andrology 6, 190-196.

Djakiew, D., Hadley, M.A., Byers, S.W. \& Dym, M. (1986) Transferrin mediated transcellular transport of iron across confluent epithelial sheets of Sertoli cells grown in bicameral cell culture chambers. Journal of Andrology 7, 355-366.

Gumbiner, B., Stevenson, B.R. \& Grimaldi, A. (1988) The role of the cell adhesion molecule uvomorulin in the formation and maintenance of the epithelial junctional complex. Journal of Cell Biology 107, 1575-1587.

Hadley, M.A., Byers, S.W., Suarez-Quian, C.A., Kleinman, H.K. \& Dym, M. (1985) Extracellular matrix regulates Sertoli cell differentiation, testicular cord formation, and germ cell development in vitro. Journal of Cell Biology 101, 1511-1522.

Hadley, M.A., Djakiew, D., Byers, S.W. \& Dym, M. (1987) Polarized secretion of androgen binding protein (ABP) and transferrin (Tf) by Sertoli cells grown in bicameral cell culture chambers. Endocrinology 120, 1097-1103.

Hamilton, D.W. (1975) Structure and function of the epithelium lining the ductuli efferentes, ductus epididymis and ductus deferens in the rat. In Handbook of Physiology Vol. 5, pp. 259-301. Eds D. W. Hamilton \& R. O. Greep. American Physiology Society, Washington.

Hinton, B.T. \& Howards, S.S. (1981) Permeability characteristics of the epithelium in the rat caput epididymidis. Journal of Reproduction and Fertility 63, 95-103.

Hinton, B.T. \& Howards, S.S. (1982) Rat testis and epididymis can transport $\left[{ }^{3} \mathrm{H}\right] 3-\mathrm{O}-m e t h y l-D$-glucose, $\left[{ }^{3} \mathrm{H}\right]$ inositol and $\left[{ }^{3} \mathrm{H}\right]$ alpha-aminoisobutyric acid across its epithelia in vivo. Biology of Reproduction 27, 1181-1189.

Hinton, B.T., Snoswell, A.M. \& Setchell, B.P. (1979) The concentration of carnitine in the luminal fluid of the testis and epididymis of the rat and some other 
mammals. Journal of Reproduction and Fertility 56, $105-111$.

Hoffer, A.P. \& Hinton, B.T. (1984) Morphological evidence for a blood epididymis barrier and the effects of gossypol on its integrity. Biology of Reproduction 30, 991-1004.

Janecki, A. \& Steinberger, A. (1986) Polarized Sertoli cell functions in a new two compartment culture system. Journal of Andrology 7, 69-71.

Jones, R., Brown, C.R., von Glos, K.I. \& Parker, M.G. (1980) Hormonal regulation of protein synthesis in the rat epididymis. Characterization of androgendependent and testicular fluid dependent proteins. Biochemical Journal 188, 667-676.

Kierszenbaum, A.L., Lea, O., Petrusz, P., French, F. \& Tres, L.L. (1981) Isolation, culture and immunocytochemical characterization of epididymal epithelial cells from pubertal and adult rats. Proceedings of the National Academy of Sciences USA 78, 1675-1679.

Klinefelter, G.R. \& Hamilton, D.W. (1985) Synthesis and secretion of proteins by perifused caput epididymal tubules, and association of secreted proteins with spermatozoa. Biology of Reproduction 33, 1017-1027.

Klinefelter, G.R., Amann, R.P. \& Hammerstedt, R.H. (1982) Culture of principal cells from the rat caput epididymis. Biology of Reproduction 26, 885-893.

Lea, O.A., Petrusz, P. \& French, F.S. (1978) Purification and localization of acidic epididymal glycoprotein (AEG): a sperm coating protein secreted by the rat epididymis. International Journal of Andrology Supplement 2, 592-607.

Lever, J.E. (1985) Inducers of dome formation in epithelial cell cultures including agents that cause differentiation. In Tissue Culture of Epithelial Cells, pp. 3-21. Ed. M. Taub. Plenum Press, New York.

Olson, G.E., Jonas-Davies, J., Hoffman, L.H. \& OrgebinCrist, M.C. (1983) Structural features of cultured epithelial cells from the adult rat epididymis. Journal of Andrology 4, 347-360.
Onoda, M., Suarez-Quian, C.A., Djakiew, D. \& Dym, M. (1990) Characterization of Sertoli cells cultured in the bicameral chamber system: relationship between formation of permeability barriers and polarized secretion of transferrin. Biology of Reproduction 43, 672-683.

Pelliniemi, L.J., Dym, M., Gunsalus, G.L., Musto, N.A., Bardin, C.W. \& Fawcett, D.W. (1981) Immunocytochemical localization of androgen-binding protein in the male reproductive tract. Endocrinology 108, 925-931.

Schuh, R., Vestweber, D., Riede, I., Ringwald, M., Rosenberg, U.B., Jackle, H. \& Kemler, R. (1986) Molecular cloning of the mouse cell adhesion molecule uvomorulin: cDNA contains a Bl-related sequence. Proceedings of the National Academy of Sciences, USA 83, 1364-1368.

Sethi, K.K. \& Brandis, H. (1980) IgG Fc-binding receptors on spermatozoa. European Journal of Immunology 10, 964-965.

Simons, K. \& Fuller, S.D. (1985) Cell surface polarity in epithelia. Annual Reviews of Cell Biology 1, 243-288.

Stevenson, B.R., Siliciano, J.D., Mooseker, M.S. \& Goodenough, D.A. (1986) Identification of ZO-1: a high molecular weight polypeptide associated with the tight junction (zonula occludens) in a variety of epithelia. Journal of Cell Biology 103, 755-766.

Stevenson, B.R., Anderson, J.M., Goodenough, D.A. \& Mooseker, M.S. (1988) Tight junction structure and ZO-1 content are identical in two strains of Madin-Darby canine kidney cells which differ in transepithelial resistance. Journal of Cell Biology 107, 2401-2408.

Wong, P.Y. (1988) Inhibition by chloride channel blockers of anion secretion in cultured epididymal epithelium and intact epididymis of rats. British Journal of Pharmacology 94, 155-163.

Received 19 March 1991 